Supporting information for

\title{
The Discovery of AM-6494: A Potent and Orally Efficacious $\beta$-Site Amyloid Precursor Protein Cleaving Enzyme 1 (BACE1) Inhibitor with in vivo Selectivity over BACE2
}

Liping H. Pettus, ${ }^{* 1}$ Matthew P. Bourbeau, ${ }^{1}$ Jodi Bradley, ${ }^{2}$ Michael D. Bartberger, ${ }^{3}$ Kui Chen, ${ }^{4}$ Dean Hickman, ${ }^{5}$ Michael Johnson, ${ }^{6}$ Qingyian Liu, ${ }^{1}$ James R. Manning, ${ }^{1}$ Adrian Nanez, ${ }^{7}$ Aaron C. Siegmund, ${ }^{1}$ Paul H. Wen, ${ }^{2}$ Douglas A. Whittington, ${ }^{3}$ Jennifer R. Allen, ${ }^{1}$ and Stephen Wood ${ }^{2}$

${ }^{1}$ Medicinal Chemistry, ${ }^{2}$ Neuroscience Research, ${ }^{3}$ Molecular Engineering, ${ }^{4}$ Discovery Technologies, ${ }^{5}$ Pharmacokinetics and Drug Metabolism, ${ }^{6}$ Research Automation and Technologies, ${ }^{7}$ Comparative Biology and Safety Studies, Amgen Discovery Research, Thousand Oaks, CA 91320

Table of Contents

Table SI-1. Cross species biochemical $\mathrm{IC}_{50}$ data for compounds $\mathbf{2 0}$ and $\mathbf{2 5} \quad$ S2

Figure SI-1. Dose response curves of $\mathbf{1}, \mathbf{2 0}$, and $\mathbf{2 5}$ tested in BACE2 cell-based assay $\quad$ S2 Experimental procudure for 20 (AM-6494) in complex with BACE1 (PDB 6PZ4) S3 
Table SI-1. Cross species biochemical $\mathrm{IC}_{50}$ data for compounds 20 and $\mathbf{2 5}$

\begin{tabular}{|c|c|c|c|c|c|}
\hline Compd & $\begin{array}{c}\text { human BACE1 } \\
\text { IC }_{50}(\mu \mathrm{M})\end{array}$ & $\begin{array}{c}\text { rat BACE1 } \\
\text { IC }_{50}(\mu \mathrm{M})\end{array}$ & $\begin{array}{l}\text { mouse BACE1 } \\
\operatorname{IC}_{50}(\mu \mathrm{M})\end{array}$ & $\begin{array}{c}\operatorname{dog} \text { BACE1 } \\
\text { IC }_{50}(\mu \mathrm{M})\end{array}$ & $\begin{array}{c}\text { monkey BACE1 } \\
\text { IC50 }(\mu \mathrm{M})\end{array}$ \\
\hline 20 & $\begin{array}{c}4.3271 \mathrm{E}-4+/- \\
1.77 \mathrm{E}-4(\mathrm{n}=17)\end{array}$ & $\begin{array}{l}6.1775 \mathrm{E}-4+/- \\
5.25 \mathrm{E}-4(\mathrm{n}=4)\end{array}$ & $\begin{array}{l}3.5975 \mathrm{E}-4+/- \\
8.54 \mathrm{E}-5(\mathrm{n}=4)\end{array}$ & $\begin{array}{c}4.205 \mathrm{E}-4+/- \\
4.66 \mathrm{E}-5(\mathrm{n}=4)\end{array}$ & $\begin{array}{l}3.4658 \mathrm{E}-4+/- \\
1.11 \mathrm{E}-4(\mathrm{n}=4)\end{array}$ \\
\hline 25 & $\begin{array}{c}2.0722 \mathrm{E}-4+/- \\
8.28 \mathrm{E}-5(\mathrm{n}=18)\end{array}$ & $\begin{array}{l}3.0675 \mathrm{E}-4+/- \\
1.72 \mathrm{E}-4(\mathrm{n}=4)\end{array}$ & $\begin{array}{l}1.9525 \mathrm{E}-4+/- \\
1.0 \mathrm{E}-4(\mathrm{n}=4)\end{array}$ & $\begin{array}{c}1.73 \mathrm{E}-4+/- \\
7.37 \mathrm{E}-5(\mathrm{n}=4)\end{array}$ & $\begin{array}{l}1.5737 \mathrm{E}-4+/- \\
5.16 \mathrm{E}-5(\mathrm{n}=4)\end{array}$ \\
\hline
\end{tabular}

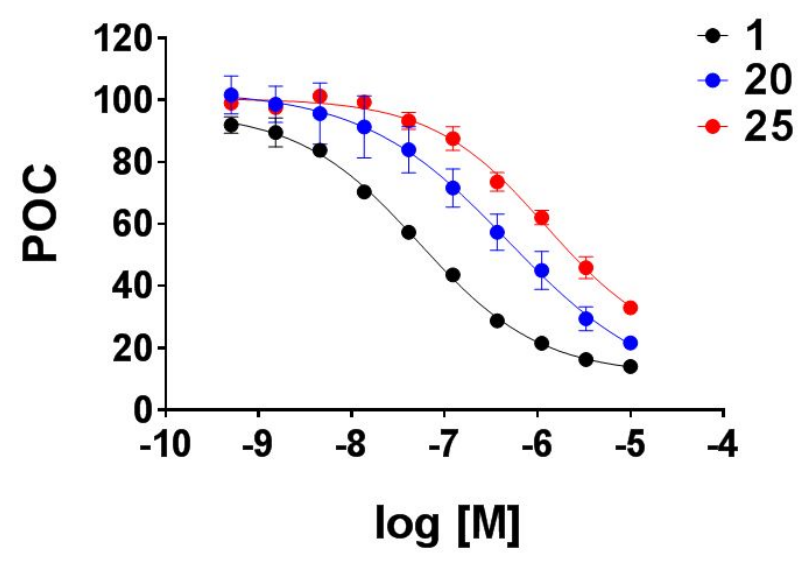

Figure SI-1. Dose response curves of 1, 20, and $\mathbf{2 5}$ tested in BACE2 cell-based (HEK293 cells) assay plotted as percent of control (POC). $\mathrm{IC}_{50}$ values are 53.4, 484.5, and $1240 \mathrm{nM}$ for $\mathbf{1}, \mathbf{2 0}$, and 25 , respectively. 


\section{Experimental procedure for 20 (AM-6494) in complex with BACE1 (PDB 6PZ4)}

The extracellular domain of BACE1 was expressed, purified, and crystallized according to published procedures. ${ }^{1}$ Inhibitor-bound BACE1 crystals were prepared by soaking apo crystals in a mother liquor solution supplemented with $1 \mathrm{mM}$ of compound 20 (AM-6494) for $5 \mathrm{~h}$ at room temperature. Crystals were transferred briefly into a cryo solution consisting of 25\% (w/v) PEG $5000 \mathrm{MME}, 0.1 \mathrm{M}$ sodium citrate ( $\mathrm{pH}$ 6.6), $0.2 \mathrm{M}$ ammonium iodide, and 20\% (v/v) glycerol prior to being flash frozen in liquid nitrogen. Diffraction data were collected on the APS SER-CAT 22BM equipped with a Mar 225 detector. Images were processed using the HKL suite of programs. ${ }^{2}$ The structures were refined using REFMAC, ${ }^{3}$ and model building was performed with COOT. ${ }^{4}$

\section{References}

(1) Patel, S.; Vuillard, L.; Cleasby, A.; Murray, C.M.; Yon, J. Apo and inhibitor complex structures of BACE ( $\beta$-secretase) J. Mol. Biol. 2004, 343, 407-416.

(2) Otwinowski, Z;; Minor, W. Processing of X-ray diffraction data collected in oscillation mode. Methods Enzymol. 1997, 276, 307-326.

(3) Murshudov, G.N.; Vagin, A.A.; Dodson, E.J. Refinement of macromolecular structures by the maximum-likelihood method. Acta Crystallogr. 1997, D53, 240-255.

(4) Emsley, P.; Cowtan, K. Coot: model-building tools for molecular graphics. Acta Crystallogr. 2004, D60, 2126-2132. 